\title{
DEVELOPING A REGISTRATION ENTRY AND QUERY SYSTEM WITHIN THE SCOPE OF HARMONIZING OF THE ORTHOPHOTO METADATA WITH THE INTERNATIONAL STANDARDS
}

\author{
İ. Şahin ${ }^{\mathrm{a},}$, Z. Alkış ${ }^{\mathrm{b}}$ \\ ${ }^{a}$ General Command of Mapping, 06100 Çankaya Ankara, Turkey - ismail.sahin@ hgk.msb.gov.tr \\ b YTU, Department of Geomatic Engineering, 34220 Esenler Istanbul, Turkey - zubeyde@ yildiz.edu.tr
}

KEY WORDS: Orthophoto, Metadata, Standard, Database

\begin{abstract}
:
Increase in the number of satellites and the utilization of digital cameras in the aerial photography has spread the use of satellite image and oriented aerial photograph as real or near-real time resolution, accessible, cost effective spatial data. Co-registered images or aerial photos corrected for the height variations and orthogonality (scale) have become an essential input for geographical information systems and spatial decision making due to their integration with the other spatial data. Beyond that, images and photographs compose infrastructure for the other information in usage of spatial data with the help of the access and query facility web providing. Although the issue of the aerial photo ortho-rectification has been solved long ago, the problems related with the storage of huge amount of photos and images, their management, processes, and user accesses have been raised. These subjects concern the multitudinous private and governmental institutes. Some governmental organizations and private companies have gained the technical ability to perform these works in recent times. This situation has lead to significant increase in the amount of aerial photograph taking and processing in one year for whole country. General Command of Mapping has been using digital aerial camera since 2008 for the photograph taking. The total area covered by the satellite images, purchased for different purposes, and the aerial photographs, taken for some revision purposes or demands of governmental and private institutes, has reached up to $200.000 \mathrm{~km}^{2}$. It is considered that, colored and high resolution orthophotos of the whole country can be achieved within four years; provided that the annual production would continue similarly without any increase in amount. From the numbers given above, it is clear and inevitable that the orthophoto production procedure must be improved in order to produce orthophotos in the same year just after the photograph takings. Necessary studies about the storage, management and presentation of the huge amounts of orthophoto images to the users must be started immediately. In this study; metadata components of the produced orthophotos compatible with the international standards have been defined, a relational database has been created to keep complete and accurate metadata, and a user interface has been developed to insert the metadata into the database. Through the developed software, some extra time has been saved while creating and querying the metadata.
\end{abstract}

\section{INTRODUCTION}

Generated digital orthophotos are stored with the explanatory information that called metadata. Metadata is also defined as common terminology set that eases consistent data collection, query and publication. Metadata states the information related with the content, quality, generation method, format and structure, generation time, access and usage limits, validity, spatial reference system and distribution mechanism of data.

Metadata can be presented either with the orthophotos or independent from the product. These information are very important for user for having the complete information about the product that he has, for using it effectively, for having the information about actuality and accuracy of the product that he use. While determination of metadata; important matters about production and information which would supply easy access to the document and user would need are supposed to be selected. Metadata related with the digital orthophotos should answer the questions; what (name of data), where (area covered by data), when (production date of data) and who (establishment that produced data).
After the completion of studies related with metadata, it's planned to present data with metadata to the users while supplying the ortofoto demands. Within the Project; metadata components are stored in tables in the database. Metadata values are also stored in the same way. Automatic implementation of addition of the metadata value to the created database, editing, querying, presentation, projection, and being copied to the demanded location processes are made by interfaces of software being used.

\section{METADATA}

Legal base which guides metadata studies and obligates improvement of implementation bases about metadata of INSPIRE is INSPIRE Directive (Aydınoğlu, A.Ç., 2007). In 3. and 6 Section. Paragraph of the directive 1 metadata is described, in the last section of 6 . item general principle notices metadata requirement is explained. 5. and 6. Sections are wholly about metadata. Those sections are summarized below (Akıncı, H., Cömert, Ç., 2009):

1. Member countries should create and keep up to date metadata about geospatial data and service. 
2. Metadata should include rights that will be implemented for accessing and using geospatial datasets and services and fee information if exists.

3. Metadata should include quality and validity information of geospatial datasets.

4. Metadata should include responsible institutes' information from establishment, management and maintenance of geospatial datasets and services.

5. Metadata should include constraints and cause of those constraints in accessing public data and services.

6. Member countries take steps in order to provide completeness and compatibility of aims specified in 3. Section 6. Paragraph of directive.

7. Member countries should establish administrative boundaries, cadastral parcels, transportation networks, hydrography, protected areas, elevation, vegetation, orthophoto and geological data and related metadata, within 2 years subsequent to acceptance of metadata implementation bases.

8. Metadata about buildings, soil, land usage, human health and security, public services, environmental surveillance facilities, production and industry facilities, agricultural and aquaculture facilities, distribution of population and demography, land management and arrangement areas, natural risk areas, atmospheric conditions, meteorological conditions, oceanographic specifications, sea areas, biogeography areas, habitat, species distribution, energy resources and mineral resources should be established lately within 5 years.
In 11. section of directive about network services, general bases about discovery, view, download and transformation services are described and in 11. Section 2. Paragraph minimum metadata elements have to be used in search criteria are listed:

1. Keywords,

2. Geospatial data and service classification,

3. Quality and validity of geospatial datasets,

4. Compatibility of realization rules of geospatial datasets provided for 7. section of directive,

5. Geographical location,

6. Implemented rights for accessing and using of spatial datasets and services,

7. Institutes responsible from establishment, management, maintenance and distribution of spatial datasets and services.

According to INSPIRE architecture spatial datasets and data services have to be defined appropriate to INSPIRE's implementation bases document (URL 1).

INSPIRE's metadata specification, define minimum metadata elements needed for defining spatial data and services compatible with specified requirements in INSPIRE Directive numbered 2007/2/EC and especially 5. and 11. sections.

INSPIRE take reference ISO 19115 for spatial data, ISO 19119 metadata standards for services and improved INSPIRE's metadata profiles. Table 1 shows metadata attributes of INSPIRE for spatial datasets (URL 2).

\begin{tabular}{|c|c|c|}
\hline ISO 19115 Core & INSPIRE & Description \\
\hline Dataset title (M) & Part B 1.1 Resource Title & - \\
\hline Dataset reference date $(\mathrm{M})$ & Part B 5 Temporal Reference & - \\
\hline Dataset responsible party $(\mathrm{O})$ & Part B 9 Responsible organization & $\begin{array}{l}\text { INPSIRE demands more. Organization } \\
\text { name and email address is obligatory. }\end{array}$ \\
\hline Geographic location of the dataset (C) & Part B 4.1 Geographic Bounding Box & INSPIRE is more restrictive. Mandatory. \\
\hline Dataset language (M) & Part B 1.7 Resource Language & - \\
\hline Dataset character set $(\mathrm{C})$ & - & - \\
\hline Dataset topic category $(\mathrm{M})$ & Part B 2.1 Topic Category & - \\
\hline Spatial resolution of the dataset $(\mathrm{O})$ & Part B 6.2 Spatial Resolution & - \\
\hline Abstract describing the dataset (M) & Part B 1.2 Resource abstract & - \\
\hline Distribution format $(\mathrm{O})$ & & - \\
\hline $\begin{array}{l}\text { Additional extent information for the } \\
\text { dataset (vertical and temporal) }(\mathrm{O})\end{array}$ & Part B 5.1 Temporal extent & INPSIRE demands more. Mandatory. \\
\hline Spatial representation type $(\mathrm{O})$ & - & - \\
\hline Reference system $(\mathrm{O})$ & - & - \\
\hline Lineage $(\mathrm{O})$ & Part B 6.1 Lineage & INPSIRE demands more. Mandatory. \\
\hline On-line resource $(\mathrm{O})$ & Part B 1.4 Resource Locator & - \\
\hline Metadata file identifier $(\mathrm{O})$ & - & - \\
\hline Metadata standard name $(\mathrm{O})$ & - & - \\
\hline Metadata standard version $(\mathrm{O})$ & - & - \\
\hline Metadata language $(\mathrm{C})$ & Part B 10.3 Metadata Language & INPSIRE demands more. Mandatory. \\
\hline Metadata character set $(\mathrm{C})$ & - & - \\
\hline Metadata point of contact (M) & Part B 10.1 Metadata point of contact & INPSIRE demands more. Mandatory. \\
\hline Metadata date stamp (M) & Part B 10.2 Metadata Date & - \\
\hline
\end{tabular}




\begin{tabular}{|l|l|l|}
\hline & Part B 1.3 Resource Type & INPSIRE demands more. \\
\hline & Part B 1.5 Unique Resource Identifier & INPSIRE demands more. \\
\hline & Part B 3 Keyword & INPSIRE demands more. \\
\hline & Part B 7 Conformity & INPSIRE demands more. \\
\hline & Part B 8.1 Conditions for access and use & INPSIRE demands more. \\
\hline & Part B 8.2 Limitations on public access & INPSIRE demands more. \\
\hline
\end{tabular}

Table 1. INSPIRE metadata for spatial data

\section{APPLICATION}

Within this study; automatic registration and queries of metadata information belonging to the orthophotos which will be produced are aimed.

It's aimed to have the metadata standards which will be generated compatible with the components defined in the ISO 19115 and INSPIRE metadata and supply the metadata needs of the country. Therefore, 37 mandatory and 92 total metadata elements are defined for digital orthophotos.

A database is defined by using MySQL and PhpMyAdmin software in order to keep defined metadata components and the metadata values belonging to orthophotos (Figure 1).

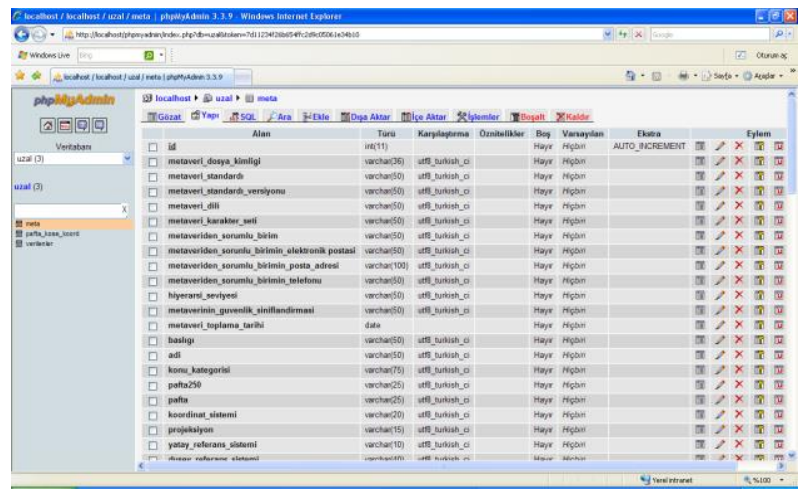

Figure 1. Database belonging to metadata components

In case of entering metadata components to database completely and accurately, adding new record, querying record by operator and demands on generated data or metadata; an interface named "METADATA SEARCH AND RECORD ADDITION SYSTEM" is prepared to prepare data and metadata automatically (Figure 2).

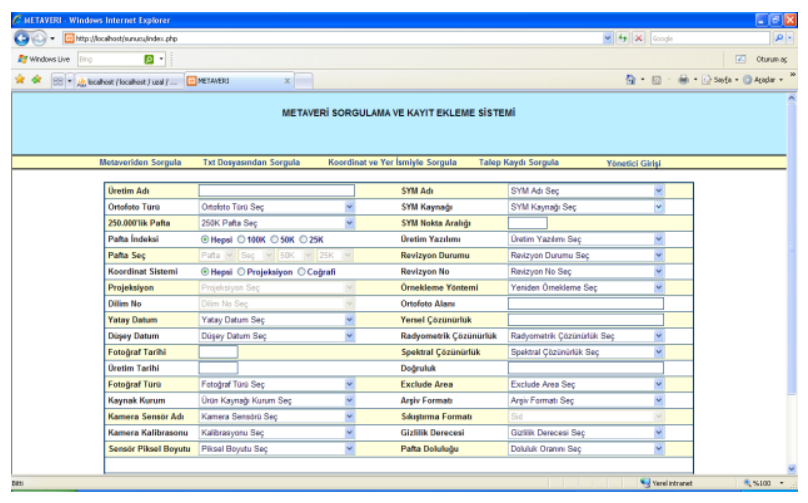

Figure 2. Metadata search and record addition system interface
When metadata search and record addition system interface comes up to the screen; search, search from txt file, search with coordinate and location name, demand record search and administrator login sections be present. In case administrator login clicked, there appears an interface (Figure 3) for entering the password that defined for administrator. After entering the password, there appears an interface (Figure 4) including "Add new record" section in addition to the sections of the interface shown in Figure 2.

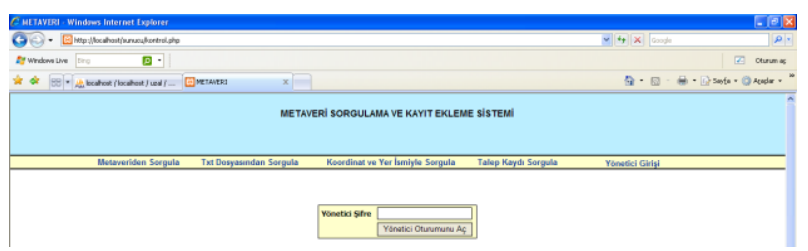

Figure 3. Administrator password login interface

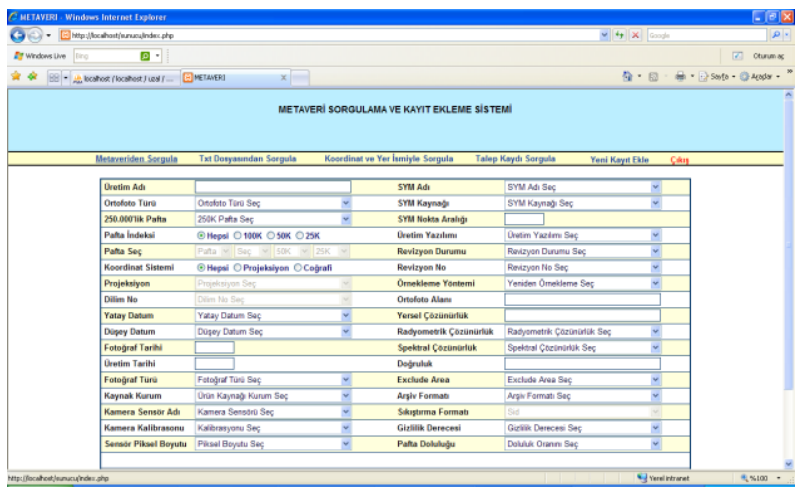

Figure 4. Metadata search and new record addition system interface that logged in with the administrator password

In the search from metadata interface, after entering any metadata component/components that we want to search, previously recorded metadata will be listed on the screen according to the search criteria (Figure 5).



Figure 5. Metadata matched with the search criteria 
We can select from the list that comes to screen and re-edit a component (Figure 6). We can also displaying the metadata of any feature on the same interface by using "browse" option (Figure 7).

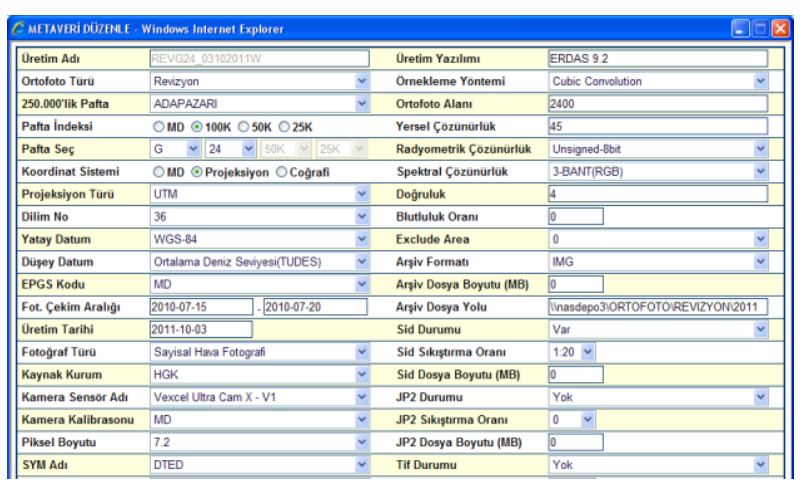

Figure 6. Metadata edit interface

\begin{tabular}{|c|c|c|c|}
\hline Üretim Adı & REVG24_03102011W & Üretim Yazılımı & ERDAS 9.2 \\
\hline Ortofoto Türü & Revizyon & Örnekleme Yöntemi & Cubic Convolution \\
\hline 250.000'lik Pafta & ADAPAZARI & Ortofoto Alanı & $2400 \mathrm{Km}^{2}$ \\
\hline Pafta indeksi & $100 \mathrm{~K}$ & Yersel Çözünürlük & $45 \mathrm{Cm}$ \\
\hline Pafta Seç & G24 & Radyometrik Çozzünürlük & Unsigned-8bit \\
\hline Koordinat Sistemi & Projeksiyon & Spektral Çözünürlük & 3-BANT(RGB) \\
\hline Projeksiyon Türü & UTM & Doğruluk & $4 \mathrm{~m}$ \\
\hline Dilim No & 36 & Bulutuluk Oranı & $\% 0$ \\
\hline Yatay Datum & WGS -84 & Exclude Area & 0 \\
\hline Düşey Datum & Ortalama Deniz Seviyesi(TUDES) & Arşiv Formatı & IMG \\
\hline EPGS Kodu & MD & Arşiv Dosya Boyutu (MB) & 0 \\
\hline Fot. Çekim Aralığı & $2010-07-15 / 2010-07-20$ & Arģiv Dosya Yolu & 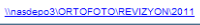 \\
\hline Üretim Tarihi & 2011-10-03 & Sid Durumu & Var \\
\hline Fotoğraf Türü & Sayisal Hava Fotografi & Sid Sikşstrma Oranı & 1:20 \\
\hline Kaynak Kurum & HGK & Sid Dosya Boyutu (MB) & MD \\
\hline Kamera Sensör Adı & Vexcel Ultra Cam X - V1 & JP2 Durumu & Yok \\
\hline Kamera Kalibrasonu & MD & JP2 Siksı̧tırma Oranı & MD \\
\hline \begin{tabular}{|l} 
Piksel Boyutu \\
\end{tabular} & 7.2 Mikron & JP2 Dosya Boyutu (MB) & MD \\
\hline SYM AdI & DTED & Tif Durumu & Yok \\
\hline SYM Kaynağı & YUKPAF-Ver.1 & Tif Sıkıştırma Oranı & MD \\
\hline SYM Nokta Aralı̆ı̆ & $10 \mathrm{~m}$ & Tif Dosya Boyutu (MB) & MD \\
\hline Revizyon Durumu & 0 & Gizlilik Derecesi & HIZMETE OZEL \\
\hline Revizyon No & 0 & Pafta Doluluğu & MD \\
\hline
\end{tabular}

Figure 7. Metadata visualization interface

Information of the Unit/establishment which made the request should be recorded to the database (Figure 8). It is needed to search which orthophotos are requested by whom later.

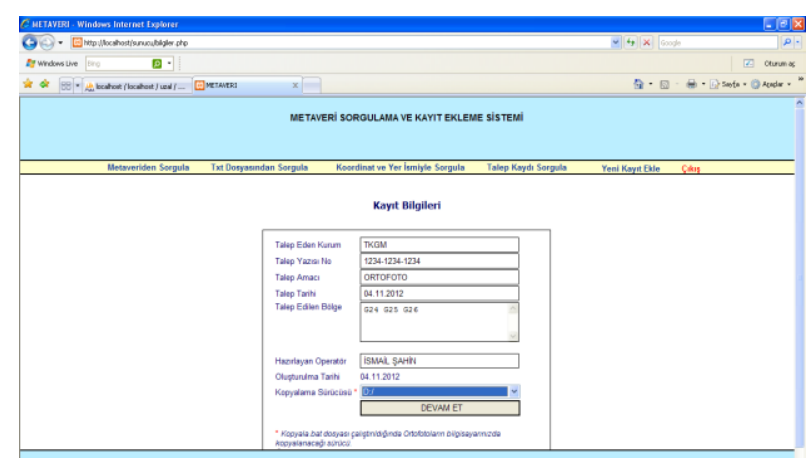

Figure 8. Recorded information interface belonging to the requested metadata

Metadata are also delivered with the requested orthophotos. Software makes the transfer operation of the related metadata automatically from the server that holds the records to the operator's computer (Figure 9).

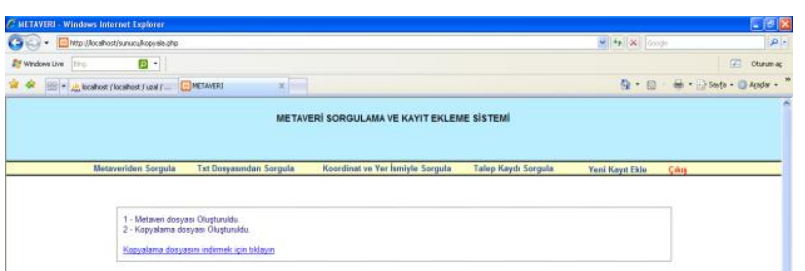

Figure 9. Record information interface of metadata

Therewithal, information of the selected metadata be written to a PDF file in order to be delivered in different features and sizes considering the who needs to know principal of the unit/establishment which requested the orthophoto (Figure 10).

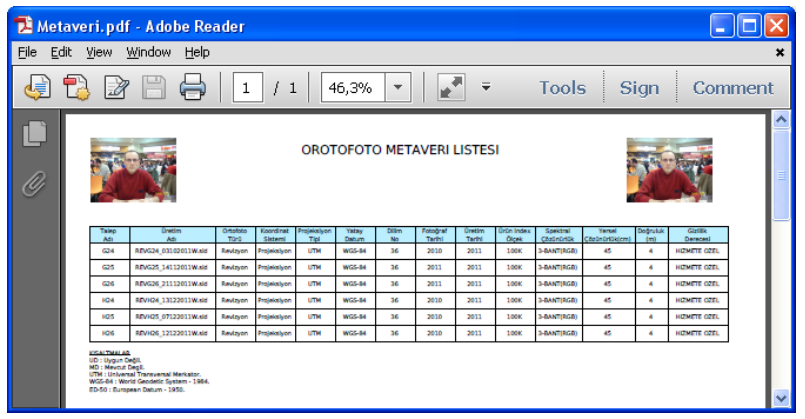

Figure 10. Orthophoto metadata list belonging to requested metadata

\section{CONCLUSIONS}

A database is created for the defined metadata components. An interface is developed to insert the metadata of produced orthophotos to database completely and quickly, and to query of the orthophoto requests from any source easily and correctly.

1. A database is defined by using MySQL and PhpMyAdmin software to store the metadata components and orthophoto metadata which are defined in this study.

2. An interface is prepared named "METADATA INQUIRY AND RECORD ADDING" to add the metadata components to the database correctly and completely, registry inquiry, and (upon request) the preparation of the data and metadata automatically by the operators.

3. Up to now; the orthophoto metadata was stored in *.xls file, automatic inquiry could not be done on the metadata and orthophoto requests. Orthophotos were searched on the server and copied the P.C of the operator manually and the metadata file was prepared in *.pdf format.

4. In the result of this study, orthophoto metadata is started to be stored in a relational database, automatic inquiry facility is acquired related to orthophoto requests for all criteria, automatic access and copy ability for the orthophotos on the server is gained and also metadata file is provided in *.pdf format automatically.

5. If we examine this study in terms of time; meeting the demand for an orthophoto was performed by the processes of request, metadata screening, selection of orthophotos, preparation of orthophotos and delivery. This process was lasting approximately 120 minutes. With the execution of metadata applications in this 
study, the process of the meeting demand is implemented as; request, inquiry and selection of the metadata, registry of the requesting information, preparation of metadata and copy files and delivery, and all this process lasts 15 minutes (Figure 11).

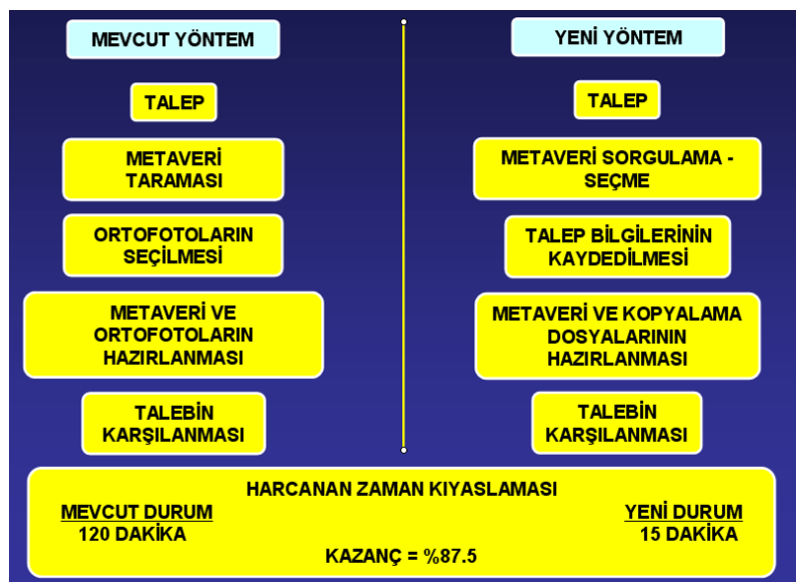

Figure 11. Time comparison of the metadata inquiry and registry

6. Numbers of requests were 20 in 2010,46 in 2011 and 93 in 2013. The time consumed for the meeting the demands were 155 hours for 2010, 310 hours for 2011 and 590 hours for 2012. Considering 87,5\% time saving with the metadata applications, in case of approximately 100 orthophoto requests for 2013, the time of the meeting the demand will decrease from 600 hours to 75 hours (Table 2).

\begin{tabular}{|c|c|c|c|c|}
\hline & $\mathbf{2 0 1 0}$ & $\mathbf{2 0 1 1}$ & $\mathbf{2 0 1 2}$ & $\mathbf{2 0 1 3}$ \\
\hline $\begin{array}{c}\text { Total Request } \\
\text { Number }\end{array}$ & 20 & 46 & 93 & $\approx 100$ \\
\hline $\begin{array}{c}\text { Time for the } \\
\text { meeting of the } \\
\text { demand (Hour) }\end{array}$ & 155 & 310 & 590 & 600 \\
\hline
\end{tabular}

Table 2. Metadata requests by years

7. With the saving of the time from meeting the demands of orthophotos, creating the metadata, inquiry, etc. It is considered that $16 \%$ increase in the orthophoto production will occur.

8. It is considered that with the increasing of the orthophoto requests in advanced years, not only for the production, but also more time will be spent for the meeting of the demand. The requests per year reach the 4 times of area of Turkey. It shouldn't be ignored that too much time would be consumed for this process.

9. Because of that; a comprehensive study should be made and a new approach should be considered in the subject of presentation of the orthophotos from the web for meeting the demand of the orthophotos.

\section{R E S O U R C E S}

Aydınoğlu A.Ç., (2007). "ISO/TC211-Coğrafi Bilgi Standartları", TMMOB The Chamber of Survey and Cadastre Engineers, The Congress of National Geographic Information Systems, KTÜ, Trabzon, November 2007.

Akıncı H., Cömert Ç., (2009). "TUCBS Ve INSPIRE Teknik Mimarisi", TMMOB The Chamber of Survey and Cadastre Engineers, 12. Turkish Survey Scientific and Technical Assembly 1115, Ankara, May 2009.

URL 1, http://inspire.jrc.ec.europa.eu/reports/ Implementing Rules/network/INSPIRETechnicalArchitectureOverview_v1.2.p df.

URL 2, http://inspire.jrc.ec.europa.eu/reports/ Implementing Rules/metadata/MD_IR_and_ISO_20090218.pdf. 